Available online on 15.12.2019 at http://jddtonline.info
Open Access to Pharmaceutical and Medical Research
unrestricted non-commercial use, provided the original work is properly cited

Open 2 Access

Research Article

\title{
Production of insulin producing cells from cord blood mesenchymal stem cells and their potential in cell therapy
} \author{
Musa' \\ 1 Faculty of Medical Laboratory Sciences, University of Khartoum, Sudan \\ ${ }^{2}$ National Center of Neurological Sciences, Sudan \\ ${ }^{3}$ Faculty of Medical Laboratory Sciences, National University, Sudan \\ ${ }^{4}$ Faculty of Medicine,University of Khartoum, Sudan \\ ${ }^{5}$ Al Neelain University, Sudan
}

Nihad Elsadig Babiker ${ }^{1,2 *}$, Alsadig Gassoum ${ }^{2}$, Mohamed Abdelrahman Arbab ${ }^{2,4}$, Sawsan Ahmed Hamed ALDeaf $^{2}$, Imad Fadl-Elmula ${ }^{5}$, Nahla E. Abdelraheem ${ }^{2,3}$, Mohamad Ahmed Ali El-Sheikh ${ }^{4}$, Hassan Hussein

\begin{abstract}
Introduction: Mesenchymal stem cells (MSCs) were described as adherent cells with a fibroblast-like appearance, have a great capacity for selfrenewal while maintaining their multipotency and differentiation into multiple tissues in vivo and in vitro. Methods: MSCs were isolated from cord blood of Sudanese donors using Ficoll-Hypaque gradient density protocol, and differentiate into $\beta$ - like cells using 3-step protocol. STZ induced diabetic rats were injected intraperitoneally with the differentiated islet $\beta$ - like cells and blood glucose levels were monitored for seven days. Results: The adherent cell appeared round and sphere after one-week of incubation, and the fibroblast-like colony was strongly attached after three weeks of seeding. The phenotyping of cells showed positivity for CD13, and negativity for CD34, CD45 and HLADR. MSCs were induced into islet-like cells using a 3-step (15-days) protocol. The differentiated cells showed positive diathizone stain and positive imunoreactivity to anti-human insulin antibody. Secretion of insulin by insulin-producing cells showed positive result with $>3.4 \mathrm{u} / \mathrm{ml}$ scale reading in high glucose concentration medium. After one-week of transplantation the level of blood glucose was reduced from 410 to 225 mg/dl in the experimental rat. Conclusion: Human UCB-MSCs can be differentiated into insulin-secreting cells invitro, and are able to produce and secrete insulin in response to high glucose concentration in vivo and in vitro.
\end{abstract}

Keywords: Cord blood, Mesenchymal stem cell, islets $\beta$-like cells

Article Info: Received 08 Oct 2019; Review Completed 19 Nov 2019; $\quad$ Accepted 25 Nov 2019; Available online 15 Dec 2019

Cite this article as:

Babiker NE, Gassoum A, Arbab MA, ALDeaf SAH, Fadl-Elmula I, Abdelraheem NE, El-Sheikh MAA, Musa HH, Production of insulin producing cells from cord blood mesenchymal stem cells and their potential in cell therap, Journal of Drug Delivery and Therapeutics. 2019; 9(6-s):65-71 http://dx.doi.org/10.22270/jddt.v9i6-s.3739

*Address for Correspondence:

Nihad Elsadig Babiker, Faculty of Medical Laboratory Sciences, National University, Sudan

\section{INTRODUCTION}

Mesenchymal stem cells (MSCs) have a potential to differentiate into diverse somatic lineages. They were adherent cells with a fibroblast-like appearance capable of differentiating into osteocytes, chondrocytes, adipocytes, tenocytes and myocytes [1]. During embryonic development MSCs are derived from the mesodermal germ layer, the mesoderm forms the connective tissue and the haematopoietic system [2]. Some scientists argue that MSCs and fibroblasts are functionally identical[3].The cultured MSCs express on their surface CD73,CD90 and CD105[4]. Stro-1, CD44, CD71 (transferring receptor), the ganglioside GD2 and CD271 (low-affinity nerve growth factor receptor).
Cell adhesion molecules including intercellular adhesion molecule-1,-2 (ICAM-1,-2), integrins, activated leukocyte-cel adhesion molecule (ALCAM) and lymphocyte functionassociated antigen 3[5].Surface markerco-stimulatory molecules CD40, CD80, and CD86 [4]. MSCs can be isolated from different tissues such as fetal or adult tissue, adipose tissues, fetal liver, cord blood and mobilized peripheral blood, fetal lung, placenta, umbilical cord dental pulp, synovial membrane, periodontal ligament, endometrium, trabecular and compact bone[5].

The cells in the umbilical cord blood (UCB) are excellent source of MSCs. However, these cells are regarded as medical waste in the delivery roomsin many hospitals [MSCs 
were isolated from the mononuclear cell [6] fraction of cord blood (CB) using various criteria including adherence to the surface of the culture medium. Negative expression of hematopoietic markers such as CD34, CD133, CD45, CD14 and positive expression of mesenchymal markers such as CD90, CD105 CD73 [7]. The isolated UCB-MSCs were shown to differentiate into a wide range of cell types. However, there is no unique phenotype for MSCs derived from CB and from other sources. Therefore, the isolation and characterization of MSCs are rely on their ability to adhere to plastic and expand [8]. In the culture, the morphology of hUCB-MSCs demonstrates a typical MSCs immunophenothypic markers and fibroblastoid morphology. The absence of endothelial CD31 and leukocyte surface markers supports the involvement of UCB-MSCs as mesenchymal progenitors. In addition, hUCB-MSCs are devoid from hematopoietic and endothelial markers such as CD14, CD28, CD31, CD33, CD34, CD45, CD56 CD133, and HLA-DR. Therefore, hUCB-MSCs can be regarded as a novel source of human MSCs for clinical applications [9]. In the present study MSCs were isolated from cord blood and differentiated in vitro into insulin-producing cells. After that, the therapeutic effect of islet $\beta$-like cells wasdetermined in vivo using experimental rats.

\section{MATERIALS AND METHODS}

\section{Cord blood samples}

This experimental study was conducted at the National Center for Neurological Sciences (NCNS) in Khartoum, Sudan. Cord blood samples were taken from healthy Sudanese women donors, at age less than 30 years subjected to full term spontaneous vaginal delivery. 5 to $10 \mathrm{ml}$ of cord blood was collected from each donor in lithium heparin containers and processed within one hour .Informed consent was obtained from parents two months before the date of delivery; all procedures and the objectives of study were clearly explained.

\section{Isolation of mononuclear cells}

In sterile falcon tube, $5 \mathrm{ml}$ of cord blood was added to $10 \mathrm{ml}$ Ficoll-Hypaque solution (1.077 g/mL; Sigma-Aldrich Co, St. Louis, Mo),two clear separate layers appeared. The mixture was centrifuged at $500 \mathrm{~g}$ for 30 minutes at room temperature, three layers were formed, mononuclear cells (MNCs) were carefully collected from the middle layer. The cells were suspended in $10 \mathrm{ml}$ of Dulbecco modified Eagle medium (Biowest co) and centrifuged at $400 \mathrm{rpm}$ for 7 minutes. The supernatant was discarded and the pellet containing MNCs, was suspended in $10 \mathrm{ml}$ of low glucose Dulbecco modified Eagle medium (L-DMEM) supplemented with 10\% fetal bovine serum (Invitrogen) and $1 \%$ of penicillin /streptomycin (Biowest co), then cells were transferred into tissue culture bottle and incubated in $5 \% \mathrm{Co}_{2}$ at $37^{\circ} \mathrm{C}$.

\section{Counting viable cells}

According UCL-EH\&S protocol, in sterile eppendorf tube 90 $\mu \mathrm{l}$ of trypan blue was added to $10 \mu \mathrm{l}$ of cells suspension, and gently vortexed. Adequate volume of the mixture was placed in haemocytometer (MARIENFELD), incubated at room temperature for two minutes, then counted using inverted microscope (Motic-AE20).

\section{Mesenchymal Stem Cells Culture}

Three ml of L-DMEM (supplemented with 10\% fetal bovine serum, $1 \%$ of $(100 \mathrm{u})$ penicillin/streptomycin) was added to $500 \mu \mathrm{l}$ of mononuclear cells in sterile tube and centrifuged at $1500 \mathrm{rpm}$ for 5 minutes. The supernatant was discarded; $3 \mathrm{ml}$ of the media was added to the pellet and mixed. The mixture was transferred into $60 \mathrm{~cm}$ petri-dish (Nest Biotechnology.com) (according to the seeding density of the petri dish) and incubated at $37^{\circ} \mathrm{C}$ in $\mathrm{Co} 2$ incubator (humidity $96 \%$ ) for $24 \mathrm{hrs}$. The culture medium was changed every three days, and cells were passage when the confluence reached $80-90 \%$.

\section{Flow cytometry}

To detect the cell surface antigen phenotype, the cells were detached after passage3 and stained with flurochrome coupled with CD13, CD34, CD45 and HLADR antibodies and analyzed with FACSCalibur (Becton Dickinson).

\section{Invitro differentiation of Mesenchymal Stem Cells}

Cells from passage 3 were induced to differentiate into insulin-secreting cells by a 3 -step protocol. In step 1 the cells were incubated for $24 \mathrm{hrs}$ in high glucose Dulbecco modified Eagle medium (H-DMEM; $25 \mathrm{mmol} / \mathrm{L}$ glucose) supplemented with $10 \%$ fetal bovine serumand $1 \mu \mathrm{M}$ of retinoic acid (sigma).Then incubated for another 2 days in H-DMEM (biowest co) with $10 \%$ fetal bovine serum. In step2; the cells were seeded in extracellular matrix (ECM) gel coated well plates(Gibco) in low glucose Dulbecco modified Eagle medium(L-DMEM), supplemented with $10 \%$ fetal bovine serum, $10 \mathrm{mmol} / \mathrm{L}$ nicotinamide (stem cell technologies) and $20-\mathrm{ng} / \mathrm{mL}$ epidermal growth factor (Thermofisher scientific) for 6 days. In step 3, to induce maturation insulin-producing cells was incubated in low glucose medium (supplemented with $10 \%$ fetal bovine serum and 10nmol/L exendin- 4(TOCRIS)) for 6 days.

\section{Dithizone staining}

The differentiated cells were incubated in $10 \mu \mathrm{l}$ of dithizone staining solution at $37^{\circ} \mathrm{C}$ for 20 minutes then examined under inverted microscope.

\section{Immunocytochemical staining for insulin}

To detect insulin production, cells were stained using Dakocytomation En Vision+ Dual system -HRP Kit (Dakocytomation) and mouse anti-human insulin antibody (ZYTOMED systems) according to the manufacture protocol.

\section{Measurement of spontaneous insulin secretion}

After 15 days of differentiation, the cells were incubated in DMEM at different concentrations of glucose $(5.5 \mathrm{mmol} / \mathrm{L}$, $28 \mathrm{mmol} / \mathrm{L})$. Insulin concentration in the media was determined using insulin ELIZA kit (IMMUNOSPEC CORPORATION) according to the manufacture protocol.

\section{Animal experiment}

Four Albino Wistar rats, aged ( 6 to 15 weeks) old, weighed (165-205g) were obtained from the Experimental Animals Center, Faculty of Veterinary Medicine, University of Khartoum, Sudan. To induce type $1 \mathrm{DM}, 30 \mathrm{mg} / \mathrm{kg}$ of sterptozotocin (STZ) solution in acidified saline (pH4.5) was injected intraperitonelly into the rats on 3 consecutive days. Rats were divided into control group and transplantation group, 2 rats for each. Three days after STZ injection, the rats in the transplantation group were injected intraperitonelly with $6 \times 10^{6}$ differentiated insulin producing cells suspended in $1 \mathrm{ml}$ of normal saline. Blood samples were collected from the tail vein every day, and glucose level in the blood was measured using blood glucose meter (ONE TOUCH, select).The experimental protocol was conducted following the guide for the care and use of laboratory animals prepared by the Faculty of Veterinary Medicine, University of Khartoum. 


\section{RESULTS}

\section{Isolation of human mesenchymal stem cells from cord} blood

All blood samples were screened for HIV, HBV, and HCV. In day one of incubation, significant number of RBCs and WBCs were seen under inverted microscope (Fig. 1), while in day 6 of incubation the RBCs and WBCs were completely absent. The number of cells per passage from cord blood samples ranged $\left(136.5 \times 10^{4}-218.8 \times 10^{4}\right)$ in passage 1 , (272 $\times 10^{4}$ $\left.560.6 \times 10^{4}\right)$ in passage 2 and (487.5 x104-1012.5 x 104) in passage 3 . The typical shape of MSCs was identified 3 weeks after incubation (Fig. 2).

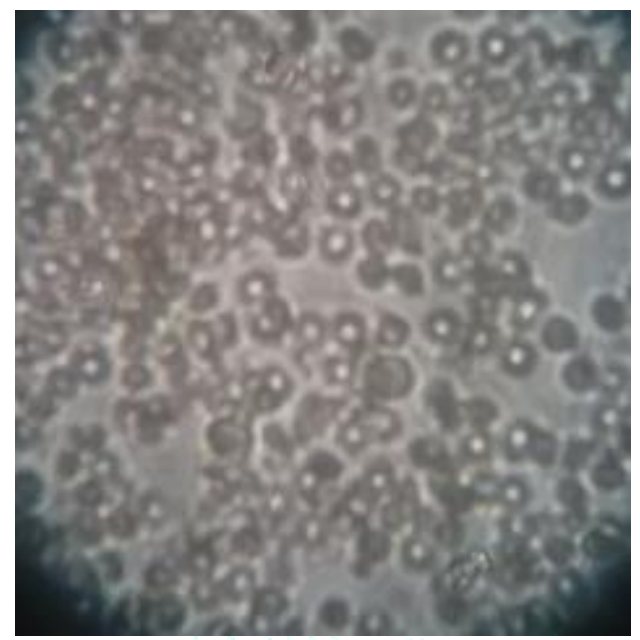

Figure 1.Day one incubation, shows the abundant number of RBCS and WBCS from cord blood samples (X40)
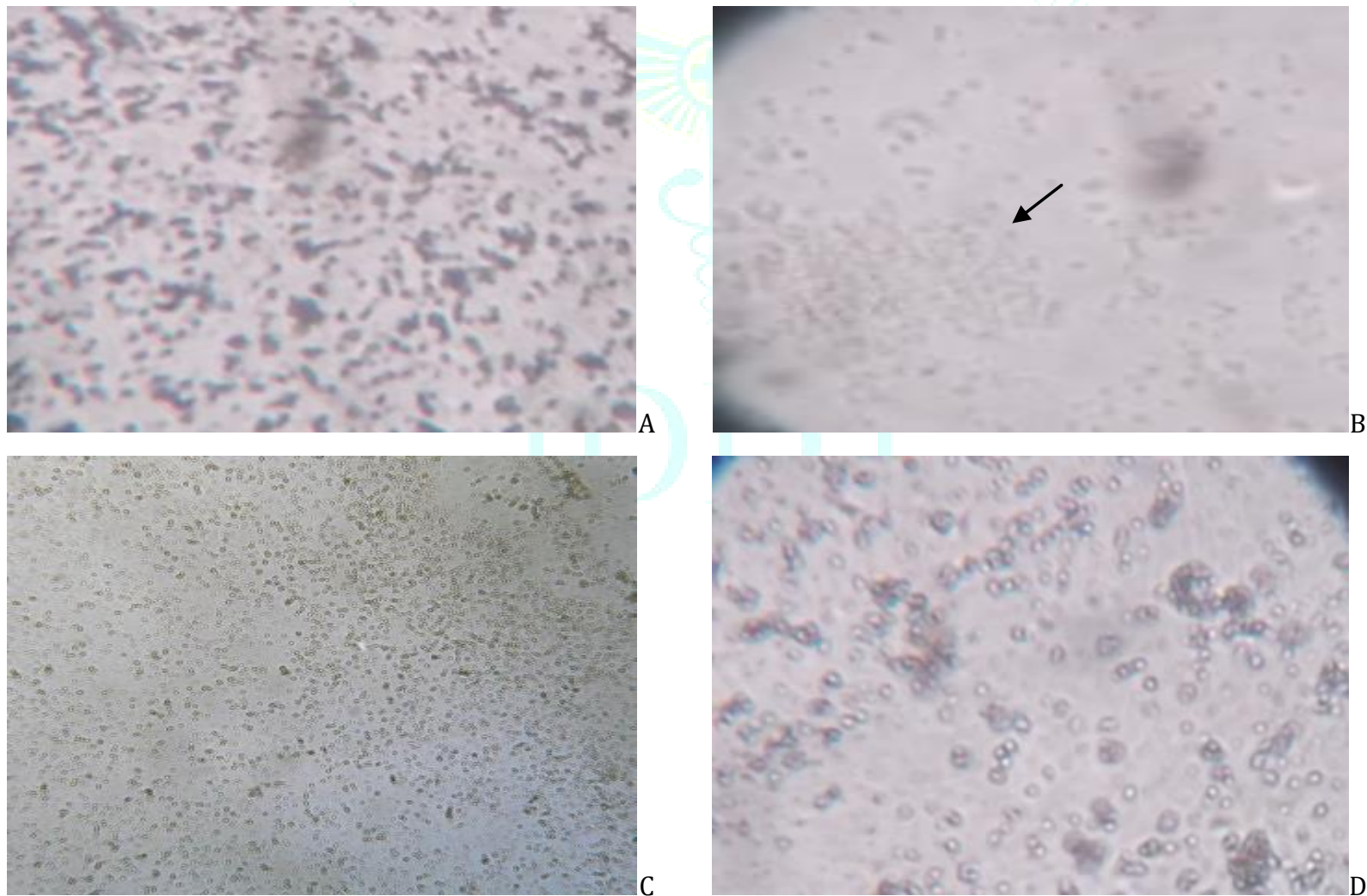

Figure 2. Microscopic photos of MSC isolation stage, A passage one shows clusters of MSC, B passage 2 shows separated cells, $\mathbf{C}$ and D passage 3 shows an increasing number of MSC. Magnification: A,B and D X40, C X10. 


\section{Phenotypic characterization of mesenchymal stem cell by flow cytometry}

Phenotypic characterization of cord blood showed positive CD13 (Fig. 3), and negative CD34, CD 45 and HLA-DR markers(Fig. 4).

1: D

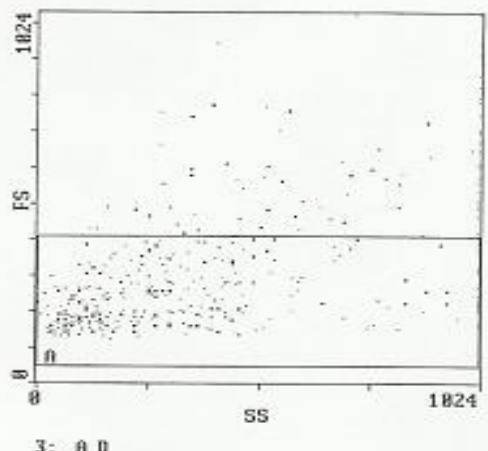

3: ค B

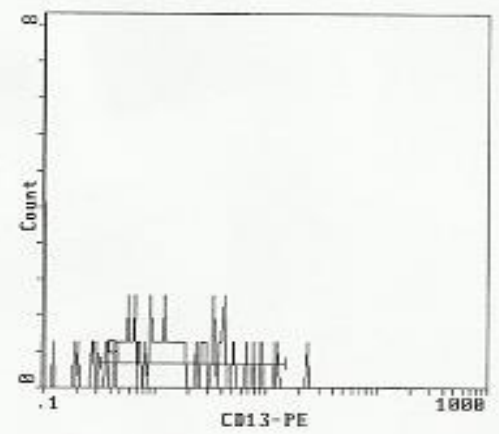

2: $\mathrm{D}$
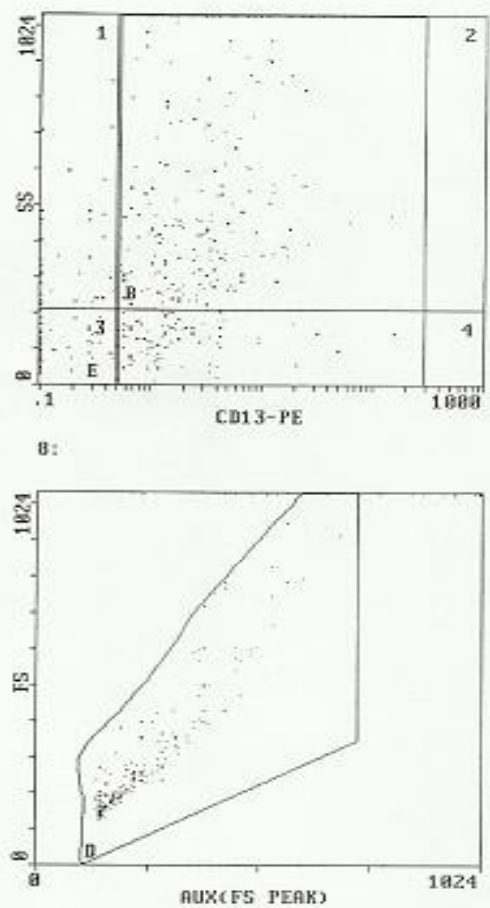

Figure 3. Flow cytometry phenotypic characterization of MSCs from the cord blood, positive for CD13

1: 1

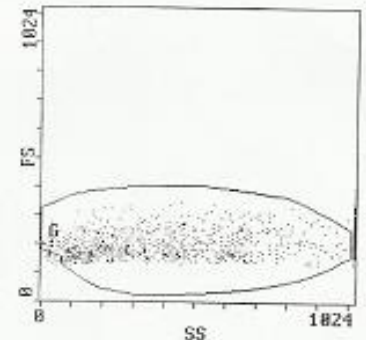

5: L.

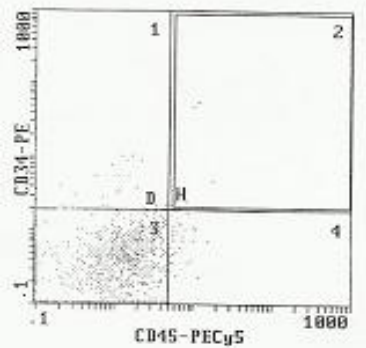

2: L

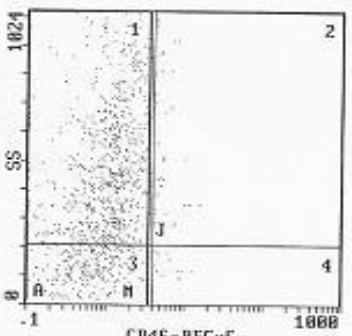

6: 1

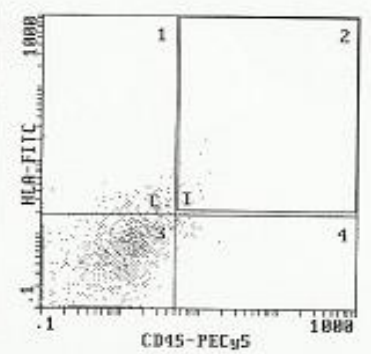

3: A I

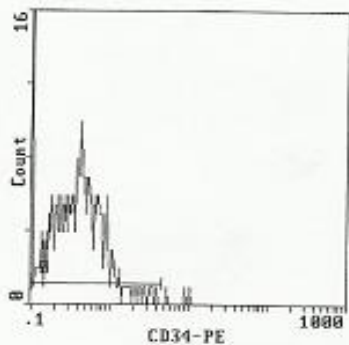

7: 1 .

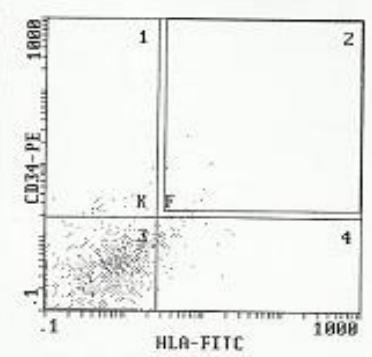

4: ค I
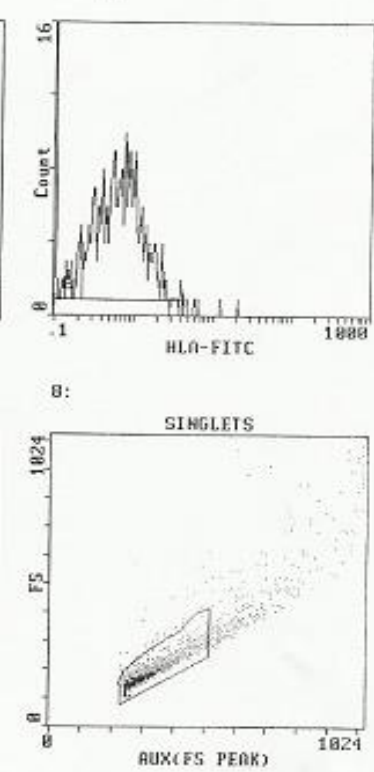

Stats: Normalized, Lisgatine: Disahled

Figure 4.Flow cytometry phenotypic characterization of MSCs from cord blood, negative for CD 34, CD45 and HLA-DR. 
In vitro differentiation of mesenchymal stem cell from cord blood into insulin -producing cell

In Step 1, no changes were detected in mesenchymal stem cell morphology. In Step 2 the proliferation rate was decreased and the MSCs shape become short and round. In Step 3 clusters of islet -like cell were formed (Fig. 5).
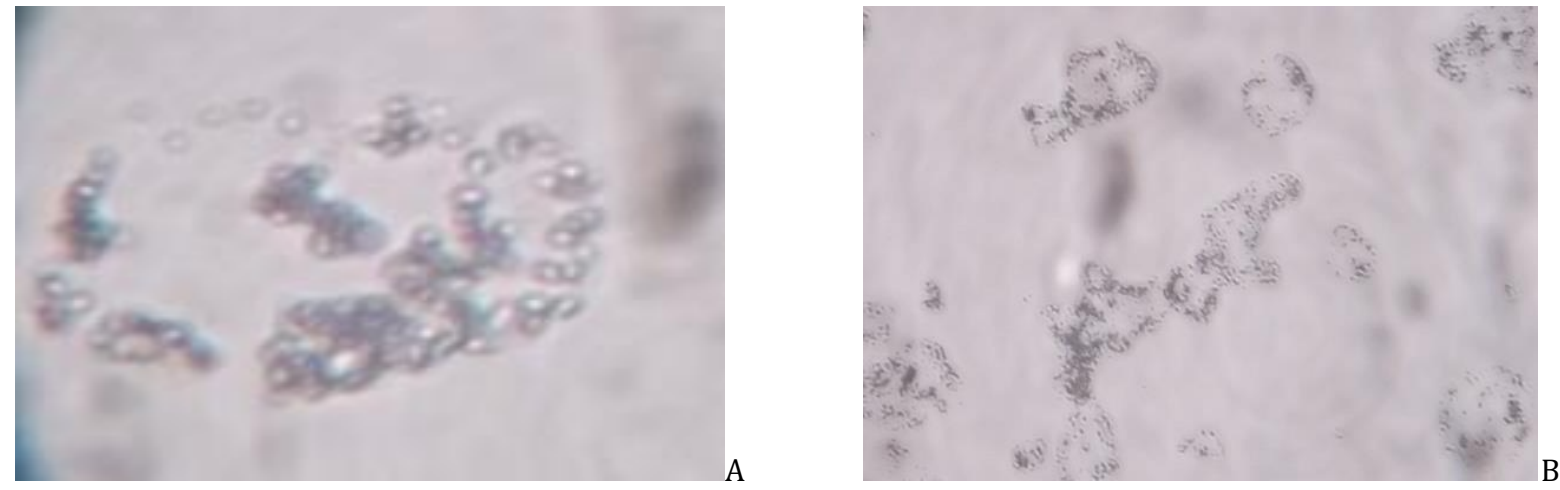

Figure5. CB-MSCs differentiated to $\beta$-like cells. A shows differentiated cells in Step2 differentiated protocol, B shows differentiated cell in Step3 differentiated protocol. Magnification x40.

\section{Detection of insulin inside the differentiated cell by diathizone stain}

Diathizone staining showed the $\beta$-like cells in red color indicating positivity insulin production (Fig.6).

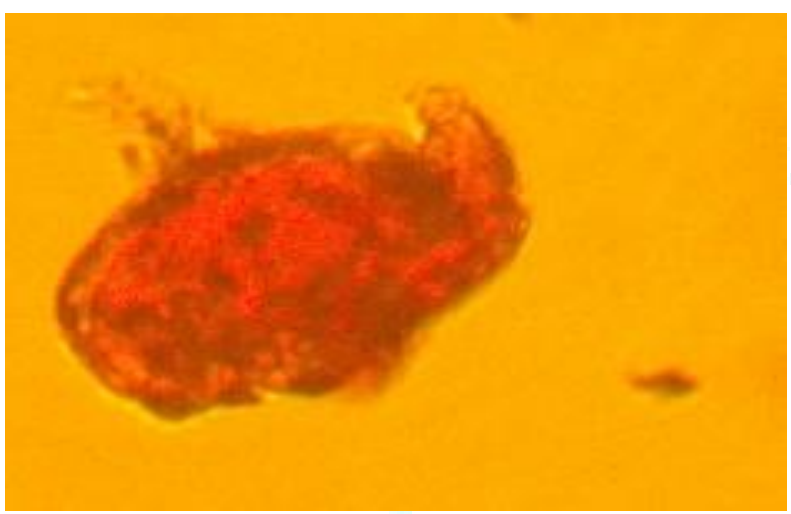

Figure 6.Diathizone stain for insulin producing cells from CB-MCS, the red color is an indicator for positive insulin production. Magnification; 40X.

\section{Immune cytochemical staining for insulin}

Positive imuno-reactivity to anti-human insulin antibody was detected in all differentiated $\beta$-like cells (Fig.7).
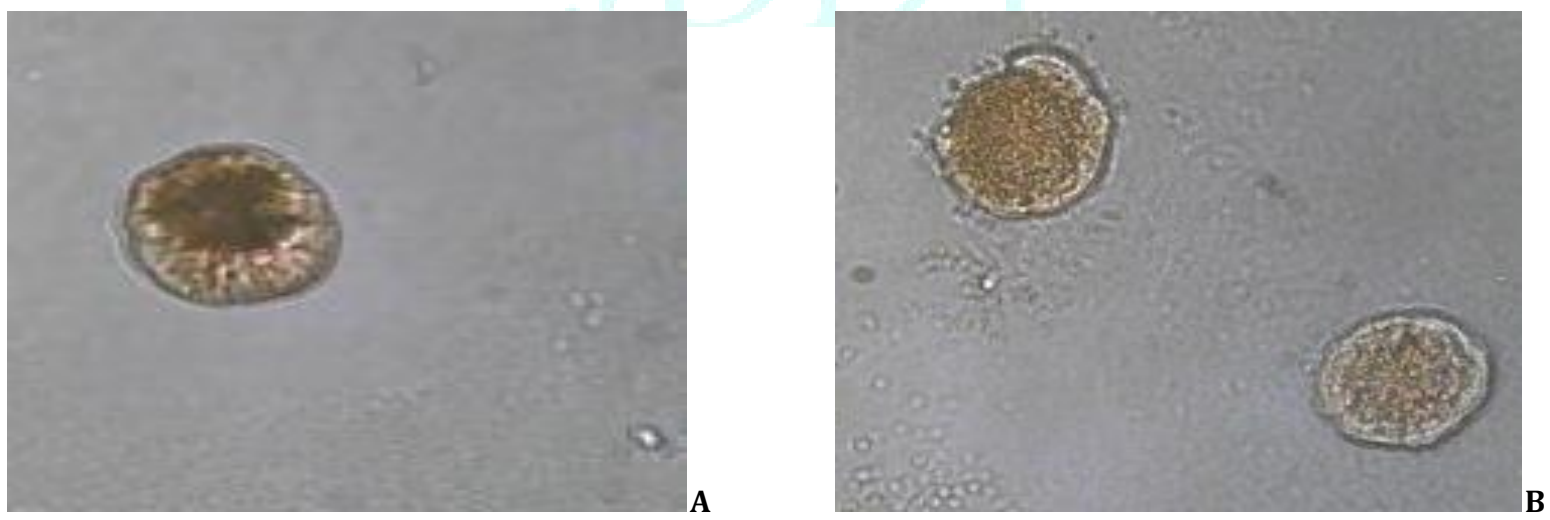

Figure 7.Imuno-reactivity to anti-human insulin antibody $\mathbf{A}$ and $\mathbf{B}, \mathrm{CB}-\mathrm{MCS}$. The brown color is an indicator for positive insulin production. Magnification; A and B X40. 
Measurement of insulin secretion by insulin- producing cells

Concerning insulin concentration; ELISA analysis showed negative results in low glucose medium with 0.00 scale reading, while high glucose medium showed positive results with $>3.4 \mathrm{u} / \mathrm{ml}$ scale reading (Table 1 ).

Table 1.Glucose challenge test

\begin{tabular}{|c|c|c|c|c|}
\hline \multirow{2}{*}{ Sample } & \multicolumn{2}{|c|}{ Low glucose concentration } & \multicolumn{2}{c|}{ High glucose concentration } \\
\cline { 2 - 5 } & Absorbance & Interpretation u/ml & Absorbance & Interpretation u/ml \\
\hline Sample 1 CB-MSC & 0.295 & 0.0 & 0.362 & 3.9 \\
\hline Sample 2 CB-MSC & 0.268 & 0.0 & 0.325 & 3.5 \\
\hline Sample 2 CB-MSC & 0.286 & 0.0 & 0.319 & 3.4 \\
\hline
\end{tabular}

\section{Animal experiment}

The rats began to show hyperglycemia after 72 hours of STZ injection and after one-week of transplantation, blood glucose levels were reduced from $420 \mathrm{mg} / \mathrm{dl}$ and $400 \mathrm{mg} / \mathrm{dl}$ to $200 \mathrm{mg} / \mathrm{dl}$ and $250 \mathrm{mg} / \mathrm{dl}$ respectively while the STZ control group showed hyperglycemia with more than 500 $\mathrm{mg} / \mathrm{dl}$.

\section{DISCUSSION}

Mesenchymal stem cells have been isolated from bone marrow and other tissues [10]. To date, BM-MSC are the best described, they serve as a standard to which other sources of MSC are compared. The present study adopted technique commonly used in the literature for MSC isolation from cord blood; Ficoll-Hypaque gradient density protocol [11] and low glucose Dulbecco modified Eagle medium (L-DMEM) supplemented with $10 \%$ of fetal bovine serum [12]. The adherent cell appeared round and sphere in shape after oneweek incubation and the fibroblast like colony was seen attached three weeks after the first seeding. Detachment of the colony was done using trypsin enzyme. While Zeddou et al described that the adherent cells appeared like macrophage with limited proliferation capacity and not detached upon trypsin treatment [13].

Based on the ISCT guide lines; CD105, CD73,CD90,CD44, CD13 were positive markers for MSC in general, while CD34, CD45 and HLADR were negative markers [14]. In this study CD13 was positive in cord blood, while CD34, CD45 and HLADR were negative. Several studies suggested cord blood as a source of MSCs, while MSCs from cord blood were present at low frequencies [13]. The previous study indicated that the rate of MSC was $29 \%$ from processed cord blood units, and it could be enhanced to $63 \%$ by coating the culture flask with FBS [15]. In the present study MSCs were isolated from all units of cord blood. In addition, the growth rate in non-coated flask was very high, but these results are not confirmed due to sample size limitation when compared with other studies (this was the first study in Sudan).

Heavy adherent fibroblastoid cells were obtained from fullterm UCB, despite the finding of many studies that the preterm UCB contains more adherent fibroblastoid cells than full-term UCB [16], In vitro differentiation of MSCs into insulin producing cells is well documented, using multistep differentiation protocols. MSC derived insulin-producing cells can be obtained from a variety of human tissues; bone marrow, adipose tissue, umbilical cord or its blood and endometrium [17]. In this study islet-like clusters were obtained from human UCB-MSCs using a 3-step protocol. These induced cells expressed pancreatic cell markers, synthesized and secreted functional islet protein (insulin).
The induced cells were cultured in high-glucose media supplemented with retonic acid. The combination of high glucose and retonic acid specifically activates pancreatic endocrine cell differentiation from UCB-MSCs [18]. Maturation factors such as nicotinamide, epidermal growth factor (EGF) and exendin-4 were used in culture. Morphologic changes of cells were observed after addition of nicotinamide and EGF in step2. Nicotinamide induces islets formation from pancreatic progenitor cells, trans differentiation and maturation into insulin-producing cells and EGF increases the number of undifferentiated cells [19] .In step 3; Exendin-4 was added in the induction system, the cells matured quickly with more formation of islet-like clusters and the functional islet's protein was detected. Gao et al demonstrated that, the microenvironments are important in differentiation of stem cells. ECM has been shown to play a crucial role in cell differentiation through rearrangement of the cytoskeletal network, essential for pancreatic progenitor cell migration, the 3-dimensional cystic structures formation and protrusion of the islet bud [20]. Another study obtained insulin-secreting cells from mouse MSCs without ECM gel coated, the induction strategies took about 2-4 months and no cluster were formed [20]. In this study, Petri dishes coated with ECM gel were used and clusters were formed with functional islet's protein secretion in 15 days.

The insulin content of insulin-secreting cells was low, and glucose induced-insulin secretion and its proportion were lower than those in native islets [11], while in our study insulin was expressed in most cells. Fenget al. proved that UCB-MSCs were capable of differentiating into insulinsecreting cells invitro by the 3-step protocol. However, these cells were immature regarding insulin production and glucose responsiveness [11]. Parekhet al. used 270 cord blood samples to evaluate the ability of cord blood mononuclear cells to differentiate into islets and found that MSCs were inefficient to dedifferentiate into beta cell because they are mesodermal in origin where beta cells are endodermal. Although the phenotypic change of MSCs into islets was reported, the functional ability of the differentiated islet-like structures was not demonstrated [22] While in this study human UCB-MSCs were capable of differentiating into insulin-secreting cells in-vitro by the 3 -step protocol and these cells were able to produce and secrete insulin in response to high glucose concentration.

In the present study, two groups of rats were used to evaluate the possibility of using IPC for therapy. In STZ treated group that received the differentiated cells (IPC), the blood glucose levels were reduced from 420 and 400 to become 200 and $250 \mathrm{mg} / \mathrm{dl}$ one week after transplantation while on Tsai et al. study, blood glucose levels decreased on 
the fourth week after transplantation to approximately $250 \mathrm{mg} / \mathrm{dl}$ in the DM rats compared to $530 \mathrm{mg} / \mathrm{dl}$ in the STZ control rats. They believed that transplantation may slow down the appearance of symptoms of DM rather than curing the disease [23].

\section{CONCLUSION}

Human UCB-MSCs are capable of differentiating into insulinsecreting cells in vitro by the 3-step protocol and able to produce and secrete insulin in vitro and in vivo in response to high glucose concentration.

\section{REFERENCES}

1- Luu, H.H., Song, W.X., Luo, X., Manning, D., Luo, J., Deng, Z.L., Sharff, K.A., Montag, A.G., Haydon, R.C., He, T.C. Distinct roles of bone morphogenetic proteins in osteogenic differentiation of Mesenchymal stem cells. Journal of Orthopaedic Research 2007; 25: 665-677.

2- Hoogduijn, M. Are mesenchymal stromal cells immune cells. Arthritis Research and Therapy 2015; 17: 88

3- Brighton, C.T, Hunt, R.M. Early histological and ultrastructural changes in medullary fracture callus. The Journal of Bone and Joint Surgery 1991; 73: 832-847.

4- Hematti, P. Mesenchymal stromal cells and fibroblasts: a case of mistaken identity. Cytotherapy 2012; 14: 516-521.

5- Zhao, Q.J., A., Ren, H.Y., Han, Z.C. Mesenchymal stem cells: Immunomodulatory capability and clinical potential in immune diseases. Journal of Cellular Immunotherapy2016; 2:3-20.

6- Pittenger, M.F., Mackay, A.M., Beck, S.C., Jaiswal, R.K., Douglas, R., Mosca, J.D., Mooman, M.A., Simonetti, D.W., Craig, S., Marshak, D.R. Multilineage potential of adult human mesenchymal stem cells. Science1999; 284:143-147.

7- Flynn, A., Barry, F., O'Brien, T. UC blood-derived mesenchymal stromal cells an overview. Cytotherapy 2007;9: 717-726

8- Hadar, A.Z., Lazarovici, P., Nagler, A. Tissue regeneration potential in human umbilical cord blood. Best Practice and Research Clinical Hematology2010; 23:291-303.

9- Malgieri, A., Kantzari, E., Patrizi, M.P., Gambardella, S. Bone marrow and umbilical cord blood human mesenchymal stem cells: state of the art. International Journal of Clinical and Experimental Medicine 2010; 3:248-269.

10- Sabatini, F., Petecchia, L., Tavian, M., de Villeroche, V. J., Rossi, G. A. Brouty-Boye, D. Human bronchial fibroblasts exhibit a mesenchymal stem cell phenotype and multilineage differentiating potentialities. Laboratory Investigation2005; 85:962-971

11- Gao, F., Wu, D.Q., Hu, Y.H., Jin, G.X., Li, G.D., Sun, T.W., Li, F.J. In vitro cultivation of islet-like cell clusters from human umbilical cord blood-derived mesenchymal stem cells. Translational Research 2008; 151:293-302. https://doi.org/10.1016/j.trsl.2008.03.003
12- Bieback, K., kinzebach, S., karagianni, M. Translating research into clinical scale manufacturing of mesenchymal stromal cells. Stem cells International 2011. Article ID 193519, 11 pages doi:10.4061/2010/193519

13- Zeddou,M.,Briquette,A.,Relic,B.,Jossr,C.,Malaise,M.G.,Gothot,A., Lachanteur,C.,Beguin,Y. The umbilical cord matrix is a better source of mesenchymal stem cells (MSC) than the umbilical cord blood. Cell Biology International 2010; 34:693-701.

14- Wankhade, U.D., Shen, M., Kolhe, R., Fulzele, S. Advances in Adipose-Derived Stem Cells Isolation, Characterization, and Application in Regenerative Tissue Engineering. Stem Cells International 2016. ID 3206807, 9

15- Kern, S., Eichler, H., Stove, J., Klater, H., Bieback, K. Comparative analysis of mesenchymal stem cells from bone marrow, umbilical cord blood, or adipose tissue. Stem cells2006; 20:294-301.

16- Tondreau, T., Meuleman, N., Delforge, A., Dejeneffe, M., Leroy, R., Massy, M., Mortier, C., Bron, D., Lagneaux, L. Mesenchymal Stem Cells Derived from CD133-Positive Cells in Mobilized Peripheral Blood and Cord Blood Proliferation, Oct4 Expression, and Plasticity. Stem Cells 2005; 23:1105-1112.

17- Zhang, X.Y., Block, N.L., Schally, A.V. Cell based therapy for treatment of diabetes mellitus: can the agonists of growth hormone releasing hormone make a contribution. International Journal of Stem Cell Research and Therapy 2016; 2(1):469-570.

18- Yang, L., Li, S., Hatch, H., Ahrens, K., Comelus, J.G., Petersen, B.E., Peck, A.B. In vitro trans-differentiation of adult hepatic stem cells into pancreatic endocrine hormone-producing cells. Proceeding of the National Academy of Sciences of the United State of America 2002; 99: 8078-8083.

19- Cras-Meneur, C., Elghazi, L., Czernichow, P., Scharfmann, R. Epidermal growth factor increases undifferentiated pancreatic embryonic cells in vitro a balance between proliferation and differentiation. Diabetes 2001; 50:15711579.

20- . Gao, R., Ustinov, J., Pulkkinen, M.A., Lundin, K., Korsgren, O., Otonkoski, T. Characterization of endocrine progenitor cells and critical factors for their differentiation in human adult pancreatic cell culture. Diabetes 2003; 52:15

21- Chen, L.B., Jiang, X.B., Yang, L. Differentiation of rat marrow mesenchymal stem cells into pancreatic islet beta-cells. World Journal of Gastroenterology2004; 10:3016-3020.

22- Parekh, V.S., Joglekar, M.V., Hardikar, A.A. Differentiation of human umbilical cord blood-derived mononuclear cells to endocrine pancreatic lineage. Differentiation2209; 78:232240

23- Tsai P.J., Wang, H.S., Shyr, Y.M., Weng, Z.C., Tai, L.C., Shyu, J.F., Chen, T.H. Transplantation of insulin-producing cells from umbilical cord mesenchymal stem cells for the treatment of streptozotocin induced diabetic rats.Journal of Biomedical Science 2012; 19-47. doi:10.1186/1423-0127-19-47. 